\title{
Entre a bondade natural e o discurso ilustrado: 0 indio em O Uraguai, de Basílio da Gama
}

Alcmeno Bastos I UFRJ

Resumo: Em O Uraguai, de Basilio da Gama, a representação do indio divide-se entre a idealização que pretende ver nele o bom selvagem $e$ uma outra, que o eleva à condição de oponente ilustrado do berói do poema. O poema não é exemplo de exaltação da brasilidade, pois o elemento nativo é derrotado pelas armas e pela razão do europeu, mas os atributos positivos do índio e o deslocamento da condição negativa de antagonista para os padres jesuitas permite vê-lo como antecipador do indianismo romântico.

Palavras-chave: Literatura brasileira; Arcadismo; Épica; Basilio da Gama.

traço mais comumente destacado pela crítica em O Uraguai ${ }^{1}$ (1769), de Basílio da Gama (1741-1795), é seu flagrante antijesuitismo, explicitado ainda nas notas que o autor acrescentou ao texto desde sua primeira edição. De fato, não resta dúvida quanto ao empenho do poeta em denegrir os padres da Companhia de Jesus, apresentados, no poema, como mentores dos índios que

1. GAMA, 1972 . 
se opuseram ao general português Gomes Freire de Andrade no episódio histórico da remoção das missões jesuíticas espanholas da banda oriental do rio Uruguai. Seriam os padres, portanto, e não os índios, na verdade apenas "bons selvagens" perfidamente mal orientados pelos seus mentores, os verdadeiros responsáveis pela resistência oferecida à execução do Tratado de Madri, de 1750. Por outro lado, o poema exalta as virtudes ilustradas do general, qualidades que existiriam também, em condições superlativas, aliás, no verdadeiro homenageado do poema: o então Conde de Oeiras e futuro Marquês de Pombal, Sebastião José de Carvalho, a quem é dedicado o soneto que antecede o poema. Deste modo, O Uraguai é, em última instância, um canto de louvor à Ilustração, de que Sebastião José de Carvalho, como déspota esclarecido, na condição de ministro plenipotenciário do Rei D. José, seria lídimo representante. Quanto a este ponto, não há divergências entre os críticos, pelo menos na essência.

Entretanto, no que diz respeito a alguns outros aspectos, dividemse as opiniões. A começar pelo enquadramento do poema no gênero épico. Antonio Candido afirma que é um "erro considerá-la epopéia, não se devendo perder de vista que é primeiramente, lírica; em seguida, heróica; finalmente, didática". ${ }^{2}$ Em outro momento, Candido diz que "quase tudo" afasta o poema do gênero épico: o assunto, reduzido e atual, quebrando a norma da distância épica; o tamanho pequeno (...) a presença da sátira e do burlesco", para concluir: "Será então um poema narrativo de assunto entre épico e político, banhado por um lirismo terno ou heróico que permite ver com simpatia a vida do índio brasileiro.” ${ }^{3}$ elemento satírico, aliás, parece comprometer irremediavelmente a epicidade do poema, como o pensa, por exemplo, o Cônego Fernandes Pinheiro, que censura a Basílio da Gama a "infeliz lembrança de admitir em sua epopéia a burlesca figura do irmão Patusca, personagem cômico e repugnante à gravidade da situação". Afrânio Peixoto, por sua vez, radicaliza: "A matéria narrada no Uraguai não daria um conto medíocre...", e "não há nenhum vislumbre de epopéia..." Também Sérgio Buarque de Holanda duvida da epicidade do poema, quando afirma que ele "escapa inteiramente aos moldes

2. CANDIDO, s.d., p. 127.

3. CANDIDO, 1977, p. 172.

4. PINHEIRO, 1978, p. 390.

5. PЕIХOTO, 1941, p. xхіх. 
camonianos". ' E Sílvio Romero, ressaltando o caráter prenunciador do poema, como antecipação romântica, é de opinião que ele se salva "por ser um fragmento mais épico-lírico do que puramente épico" ${ }^{7}$ A inadequação do poema aos moldes clássicos é também ressaltada por José Veríssimo, para quem o assunto "daria apenas um episódio em poema de maior vulto", além de achar que lhe falta "o recuo necessário no tempo para uma idealização verdadeiramente poética do acontecimento".

Já estudos mais recentes têm reconhecido O Uraguai como poema épico, senão como uma epopéia. Anazildo Vasconcelos da Silva, refutando a incidência lírica no poema como impedimento à epicidade do texto, e levando em conta que "são os índios que, ao nível do relato, satisfazem as exigências épicas do herói”, afirma que "O Uraguai, considerado a partir da perspectiva indígena, é uma epopéia legítima e Cacambo, seu verdadeiro herói”. ${ }^{9}$ Vânia Pinheiro Chaves, lembrando que fazê-lo "é assumir posição contrária à de uma parcela significativa de seus receptores, que, com diversos argumentos, lhe têm recusado quer o caráter brasileiro, quer a qualidade de epopéia ou a própria natureza de poesia épica", classifica o poema como "uma epopéia brasílica do Setecentos".

Nos dois casos, e por força de maior rigor teórico, os recentes defensores da epicidade de O Uraguai, na sustentação de seus pontos de vista, passam em revista os conceitos de épica e de epopéia. Historiam as transformações ocorridas no(s) modelo(s) épico(s) ocidental(is), e disso decorre uma visão mais flexível, que lhes permite reconhecer nos "defeitos" até então apontados do poema apenas variantes, freqüentemente saudáveis, que de modo algum podem desqualificá-lo, como é o caso da recusa da oitava camoniana para seus versos decassilábicos, ou a pequena extensão do episódio histórico que o fundamenta. Para um terceiro estudioso de nossos dias, Ivan Teixeira, "a escolha do assunto reduzido possibilitou um poema enxuto, de dimensões mínimas e enorme significação", pois "revive toda a formação do Brasil pela miniaturização de uma parte, isto é, apreende a estrutura política do colonialismo através da efabulação de um dos seus episódios", de modo que "do assunto

6. HOLANDA, 1991, p. 133.

7. ROMERO, 1960, p. 418.

8. VERÍSSIMO, 1977, p. 63.

9. SILVA, 1987 , p. 29-30.

10. CHAVES, 2000, p. 49. 
particular de uma guerra o poeta extraiu uma síntese da história do Brasil". ${ }^{11}$ No seu entender, "O Uraguai representa a única manifestação realmente viva de poesia épica no período colonial brasileiro." ${ }^{12}$

Também não há acordo no que se refere à possível brasilidade do poema. Nunca passou despercebida certa contradição entre o propósito declarado de exaltação do herói português e a indiscutível simpatia manifestada em relação aos índios, funcionalmente seus antagonistas, o que poderia ser tomado já como manifestação de indianismo. Afinal, muitos se perguntaram, a favor de quem estaria o poeta? José Veríssimo afirma que "o poema canta Portugal e a sua civilização", corrigindo Camilo Castelo Branco, pois "não é Cacambo, mas o general português Gomes Freire de Andrade" o herói do poema, e que se alguns índios "aparecem grandes e heróicos no poema, assim o exigia a estética do gênero". ${ }^{14}$ Portanto, segundo Veríssimo, o que de positivo pode ser visto em Sepé e Cacambo, os principais chefes indígenas, decorreria de uma imposição universal da épica, não de algum intuito de fazer deles representantes virtuosos da brasilidade. Eugênio Gomes não hesita em dizer que "o intuito político de Basílio da Gama, no Uraguai, era lisonjear os colonizadores portugueses, em detrimento de sua própria nacionalidade", apesar de reconhecer que "o que ali sobressai de maneira notável é a luta do autóctone pela terra nativa”. "José Aderaldo Castello pensa tratar-se de "um problema de interpretação controvertida saber onde é possível reconhecer sentimento nativista ou inspiração americanista em Basîlio da Gama". Para Antonio Candido, a boa vontade do poeta para com os índios não é ainda indianismo legítimo, pois este não foi, como o seria para os românticos, "uma vivência", mas "antes um tema arcádico transposto em roupagem mais pitoresca", 17 o que significa não existir no poema uma ótica não-lusitana, brasileira. Opinião diferente é a de Sérgio Buarque de Holanda: parece-lhe que nos índios de $O$ Uraguai o poeta depositou,

11. TEIXEIRA, 1996, p. 35

12. TEIXEIRA, 1996, p. 35.

13. VERÍSSIMO, 1977, p. 60.

14. VERÍSSIMO, 1977 , p. 60.

15. GOMES, 1958 , p. 40.

16. CASTELlO, 1969, p. 170.

17. CANDIDO, s.d., p. 133. 
em grau equivalente, o mesmo sentimento de orgulhosa fidelidade à terra natal, que o teria levado a dizer-se 'americano' - designação ainda pouco usual para os brancos do Novo Mundo - quando se inscreveu na Arcádia de Roma, e 'brasileiro', quando escreveu ao Metastásio. ${ }^{18}$

Ślvio Romero observa que a derrota dos índios é "uma espécie de preito à verdade histórica", de que, evidentemente, o poeta não poderia fugir, mas que, numa forma moderada de compensação poética - se bem que inconsciente -, os índios "ocupam a melhor parte do poema" . ${ }^{19}$ Considerandose que neles estaria manifestada a brasilidade possível, no poema e naquele momento histórico, não há dúvida de que, para Sílvio Romero, O Uraguaié etapa importante na construção dessa brasilidade. David Miller Driver ${ }^{20}$ aborda a questão das verdadeiras simpatias de Basílio da Gama imaginando que o leitor, ao final de O Uraguai, irá perguntar-se sobre quais lutadores saem do palco cobertos de glória. Na sua opinião, certamente, não Gomes Freire de Andrade, apesar de suas inegáveis qualidades, mas sim Sepé, Cacambo e Lindóia, de modo que "a glória maior que Basílio da Gama atribui às suas personagens indígenas, consciente ou inconscientemente, é a melhor prova da predominância de suas tendências americanistas"; no original em inglês: "The greater glory that Gama, consciously or unconsciausly [sic] gave to his Indians characters is the best proff of his predominant Americanist tendency." "Ivan Teixeira, que refuta a "apropriação romântica" de O Uraguai como explícita manifestação nacionalista, atenta para a duplicidade de enfoques que o texto permite, pois se "por um lado, o poema exalta a projeção de Portugal sobre a Colônia Brasileira; por outro, glorifica os primitivos habitantes do país, transformando-os em símbolo da resistência contra a dominação estrangeira". ${ }^{22}$ No entanto, ao eleger a primeira leitura como a que "parece ser a única compatível com a organicidade do poema", observa que ela não exclui a segunda, mas esta "inviabiliza a primeira e mutila o poema", de modo que "o índio em o Uraguay, antes de ser índice de nativismo do autor, deve ser entendido como expressão do louvor à política pombalina na

18. HOLLANDA, 1991, p. 149.

19. ROMERO, 1960, p. 415 .

20. DRIVER, 1942, p. 30-31.

21. DRIVER, 1942, p. 31.

22. TEIXEIRA, 1999, p. 507.

23. TEIXEIRA, 1999, p. 507. 
América”. ${ }^{24}$ Portanto, no seu entender, nada de nativismo, menos ainda, é claro, de nacionalismo, na presença do índio no poema de Basílio da Gama. Vânia Pinheiro Chaves, reconhecendo embora que na época de feitura do poema não vigorasse no Brasil "a clara pretensão de romper com a dominação portuguesa", não só defende o conteúdo de brasilidade de O Uraguai como o conceitua de modo surpreendentemente diverso do habitual. Parece-lhe que Basílio da Gama, estando "em sintonia com os sentimentos de seus compatriotas, já pôde defender interesses fundamentalmente brasileiros", de modo que

a brasilidade de O Uraguai reside no fato de ele ter dado forma poética à ação e à ideologia dos colonos brancos que se apossaram do território americano e subjugaram as populações nativas, obrigando-as a participar da nova sociedade que estavam criando e na qual se instalavam como classe político-economicamente dominante e como elite cultural. ${ }^{26}$

O tratamento dispensado ao índio é tema correlato ao da possível brasilidade da ótica do poeta em O Uraguai. E também aqui grassa a divergência, exceto no reconhecimento da já mencionada simpatia que cerca o elemento nativo. É usual vê-lo como ilustração do mito, já então corrente, do bom selvagem. Mário Camarinha da Silva afirma-o na Apresentação de uma das edições do poema, a de que nos servimos neste trabalho: os índios seriam "bons selvagens que o poeta imagina vivendo numa natureza amena, quase idílica, mas presas da Superstição e do Fanatismo que lhes incutiam os bons padres espanhóis". 27 Sílvio Romero considera mais positivo o fato de Basílio da Gama não contentarse com a idealização do índio, que existe no poema, sim, porque "não são tomados ao vivo; são afetados e adornados epicamente", e sim avançar até o propósito etnológico de não mostrar "o português só, ou o índio só", mas "em face um do outro", complementando com a observação, na verdade extemporânea, de que "Falta aí o negro". ${ }^{28}$ José Aderaldo Castello ressalta justamente o fato de Basílio da Gama ter escapado do condicionamento documentalista que marcara

24. TEIXEIRA, 1999, p. 507.

25. CHAVES, 2000, p. 251.

26. CHAVES, 2000, p. 251.

27. SILVA, 1972, p. 11

28. ROMERO, 1960, p. 417. 
os cronistas anteriores e que viria a impregnar até o "poema que vem logo a seguir, o Caramuru", pois opta por mostrar o índio "em ação, e na ação que mais lhe convinha, a guerreira". ${ }^{29}$ E o Cônego Fernandes Pinheiro, cuja apreciação do poema pauta-se por uma preocupação marcante em filiá-lo à tradição clássica - dentre outras marcas dessa filiação, diz que Sepé, "nesta Ilíada americana ocupa o lugar de Heitor", com o que, aliás, concorda Vânia Pinheiro Chaves, para quem "Cepé assemelha-se à figura de Heitor, tal como ela é construída na Ilíada e na Eneida" ${ }^{31}$-, sai-se com uma surpreendente e enfática afirmação: Cacambo é "o verdadeiro herói do poema", e ainda que sob a marca da primitividade, sua fala "respira nobreza e dignidade".

O fundamento histórico do poema é a

expedição do Governador do Rio de Janeiro às missões jesuíticas espanholas da banda oriental do rio Uruguai, cujos índios se haviam rebelado contra a entrega dos seus Sete Povos (São Borja, Santo Ângelo, São João, São Lourenço, São Luís, São Miguel e São Nicolau) em troca da colônia portuguesa do Sacramento, praça militar que os portugueses haviam fundado em 1680 na margem cisplatina, em frente mesmo a Buenos Aires ${ }^{33}$

como decorrência do Tratado de Madri, firmado por Portugal e Espanha em 1750 e que visava a revogar os termos do Tratado de Tordesilhas, de 1494, com o qual as duas potências ibéricas partilhavam entre si as terras a serem descobertas nos dois hemisférios. Narra-se nele a vitória do general português, em 1756, após a fracassada embaixada dos chefes indígenas Sepé e Cacambo, que tentam demovê-lo da missão. O primeiro morre no combate que se segue. O segundo, após um sonho em que lhe aparece Sepé, ateia fogo à vegetação em torno do acampamento dos brancos e foge em seguida para sua aldeia. Ali, por maquinações do padre jesuíta Balda, é preso e morto, para que sua esposa, Lindóia, possa

29. CASTELLO, 1969 , p. 170.

30. PINHEIRO, 1978, p. 390.

31. CHAVES, 2000. p. 156.

32. PINHEIRO, 1978, p. 384.

33. SILVA, 1972, p. 9. 
desposar Baldetta, protegido do padre, talvez seu filho. Por artes da feiticeira Tanajura, Lindóia tem uma visão profética do terremoto de Lisboa, de sua reconstrução pelo Conde de Oeiras, futuro Marquês de Pombal, e da derrocada final de Ordem dos Jesuítas. As tropas de Gomes Freire de Andrade avançam contra a aldeia indígena, onde aconteceria o casamento de Lindóia com Baldetta. Esta, fiel à memória de Cacambo, foge para um bosque próximo e lá se deixa picar por uma serpente venenosa, morrendo em seguida. À chegada do general português e suas tropas, todos fogem, incendiando a aldeia, por incitação dos padres. Gomes Freire de Andrade penetra na aldeia, vitorioso, mas triste, pois fora obrigado a usar da força das armas para dobrar os índios e fazer valer os desígnios dos reis de Portugal e Espanha, o que desagradava à sua índole essencialmente civilizadora.

Do ponto de vista funcional, o herói do poema, considerado como tal aquele que se faz vitorioso no confronto bélico, e que recebe do poeta os epítetos mais enobrecedores, é, portanto, não um dos destemidos indígenas postos em cena, mas o general português Gomes Freire de Andrade. Gomes Freire de Andrade, no poema, é perfeita encarnação do ideal iluminista do chefe guerreiro que antes faz uso da razão que das armas, mas que não hesita, em último caso, em a elas recorrer para impor sua vontade. Deixa isso claro, primeiro, numa conversa com um ajudante, Meneses (Francisco Antonio Cardoso de Meneses), que lhe sugerira que "(...) só por força de armas [poderemos]/ "Inteiramente sujeitar os povos.” (I, 23-24). Responde-lhe o general: “(...) "Tentem-se os meios/ "De brandura e de amor; se isto não basta/ "Farei a meu pesar o último esforço." (I, 26-28). Depois, na longa (64 versos) resposta que dá a Cacambo, um dos líderes indígenas, que ousara chamar sua atenção para o fato de que "o nome dos reis" (II, 108) - de Espanha e de Portugal - não o assustava, até porque eles, os índios, não tinham "outro rei mais que os padres" (II,110). Após um afago ao embaixador dos índios rebelados, quando a ele se dirige chamando-o de "alma grande" (II, 112), e lamentando que não combata "por melhor causa" (II, 113), explica-lhe pacientemente as razões superiores que devem prevalecer sobre as dos índios, que podem ser sintetizadas na afirmação de que "O sossego da Europa assim o pede" (II, 138). Procura, com isso, fazer valer um conceito de liberdade diverso daquele defendido por Cacambo, transformando em negatividade aquilo de que o índio tanto se orgulhava, e coroando sua argumentação com o paradoxo de que, àquele tipo de liberdade, isto é, o "viver errantes e dispersos", sempre "em dura guerra" (II, 120 e 122, 
respectivamente), "Melhor a escravidão que a liberdade". Por fim, após declarar formalmente os índios rebeldes, e logo em seguida transferir a culpa para os padres jesuítas, a quem acusa de escravizá-los (II, 143) e de incitá-los a uma luta desigual e fadada à derrota, encerra sua fala com inequívoca ameaça, reafirmando sua condição de representante metonímico dos reis que "estão na Europa":

"Os reis estão na Europa; mas adverte:

"Que estes braços, que vês, são os seus braços.

"Dentro de pouco tempo um meu aceno

"Vai cobrir este monte e essas campinas

"De semivivos palpitantes corpos.

"De míseros mortais, que inda não sabem

"Por que causa o seu sangue vai agora

"Lavar a terra e recolher-se em lagos.

"Não me chames cruel: enquanto é tempo

"Pensa e resolve" (...) (II, 157-166)

Mesmo após ficar claro ser inevitável a guerra, Gomes Freire de Andrade dá ainda prova de sua magnanimidade, presenteando os embaixadores dos índios e garantindo-lhes o regresso livre aos seus. Como os índios, instigados pelos padres jesuítas, resolvem oferecer resistência à mudança determinada pelas duas potências européias, o conflito bélico torna-se inevitável, de modo que os "montes" e as "campinas" efetivamente cobrem-se de "semivivos palpitantes corpos", cujo sangue lava a terra, como previra a fala do general.

Deste modo, por exigência da fundamentação histórica do enredo, e de acordo com as convenções do gênero épico, os índios cumprem a função de antagonistas do herói, obstáculo vivo à consecução dos seus objetivos. E como, ainda por determinação do gênero épico, tal antagonista deve ter atributos positivos suficientes para engrandecer a vitória do herói, o índio de O Uraguai, por suas inegáveis qualidades, não é mais apenas a besta-fera mencionada por Bento Teixeira na sua Prosopopéia (1601), ou o ancestral que não dignifica sua descendência involuntária, como nos poucos poemas de Gregório de Matos que aludem, ainda que de forma indireta, ao índio, ou a presa fácil da ação catequética que o libertará das trevas do primitivismo pagão, como na poesia e no teatro catequéticos de José de Anchieta, mas um ser dotado de altíssimo senso de dignidade, inflexível na defesa de seus interesses, ainda que, do ponto de vista do poeta-narrador, sejam interesses equivocados e, em última instância, 
interesses alheios, pois os verdadeiros mentores da reação oferecida pelos índios são os padres jesuítas. Veja-se, por exemplo, a exemplar racionalidade dos argumentos de Cacambo, na embaixada junto ao general português. Não parece ele simplesmente um bom selvagem, "vivendo numa natureza amena, quase idílica, mas presa da superstição e do Fanatismo que lhes incutiram os bons padres espanhóis". ${ }^{34}$ Antes também é ele um digno representante do pensamento ilustrado da época em que decorre a ação. Sua fala é engrandecida em sua eficácia retórica pela altaneria do seu discurso de advertência, no qual enfatiza o destemor com que se apresenta ao inimigo, "desarmado e só”, fiado, portanto, no poder persuasivo de suas razões, na tentativa malograda de convencer o general português a deixálos ficar nas suas terras:

"Eu, desarmado e só, buscar-te venho.

"Tanto espero de ti. E enquanto as armas

"Dão lugar à razão, senhor, vejamos

"Se se pode salvar a vida e o sangue

"De tantos desgraçados. (...)

(...)

"As campinas que vês e a nossa terra

" - Sem o nosso suor e os nossos braços -

"De que serve ao teu rei? Aqui não temos

"Nem altas minas, nem caudalosos

"Rios de areias de ouro. (...)

(...)

"Volta, senhor, não passes adiante.

"Que mais queres de nós? Não nos obrigues

"A resistir-te em campo aberto. Pode

"Custar-te muito sangue o dar um passo.

"Não queiras ver se cortam nossas frechas.

"Vê que o nome dos reis não nos assusta.

(II, 55-106)

Como se vê, o discurso de Cacambo é análogo ao do seu oponente civilizado. E, do ponto de vista estrutural, sua relevância expressa-se na homóloga extensão que lhe atribui o poeta, reservando-lhe nada menos que 63 versos. Cacambo, que prima por apresentar-se antes como parlamentar que como

34. SILVA, 1972, p. 12 
guerreiro ("desarmado e só" - II, 55, reiteremos), destaca inicialmente a vastidão do rio Uraguai e a quantidade de gente que dele "bebe", isto é, vive às suas margens. Faz em seguida breve histórico do passado de escravização a que os europeus já haviam submetido os índios - "os nossos avôs fossem despojos/ "Da perfídia da Europa" (II, 51-52) - e convida o adversário a nada menos que ao diálogo, portanto ao embate civilizado de idéias, "Enquanto as armas/ "Dão lugar à razão" (II, 56-57, itálico nosso). Depois, sua argumentação é reforçada com a lembrança de que ali não existiam os tão cobiçados metais que acaloravam a imaginação dos europeus, o que parecia menos justificar a empreitada lusoespanhola. Por fim, profere a ameaça, firme, vazada em linguagem elevada, mas sem soberba, apenas objetiva.

A posição do outro embaixador dos índios, Sepé, difere em parte da de Cacambo. Sua fala é curta (apenas 14 versos), impulsiva, reafirma o amor à liberdade - se bem que a deposite espontaneamente nas mãos dos padres: "Desconhecemos, detestamos jugo/ "Que não seja o do céu, por mão dos padres." (II, 182-183) - e o direito à posse da terra, herdada dos antepassados e a ser transmitida, também livre, aos filhos:

"Que estas terras, que pisas, o céu livres

"Deu aos nossos avôs; nós também livres

"As recebemos dos antepassados.

"Livres as hão de herdar os nosso filhos.

(II, 178-181)

Apesar da intensa paixão com que defende sua causa, também não falta racionalidade ao discurso de Sepé. Sua declaração de guerra é quase protocolar, o que demonstra elevado grau de civilidade, por paradoxal que isso possa parecer: “- 'Enfim, quereis a guerra, e tereis guerra." - II, 189. O "Enfim” denota esgotamento do poder argumentativo e inexistência de alternativa, de modo que a culpa pelo desentendimento é automaticamente repassada para o outro contendor. Ainda assim, a declaração é precedida de uma derradeira demonstração de esperança na força superior da razão, pois transfere a terceiros, nem tão insuspeitos, pois estão contidos na expressão "vosso Mundo" (itálico nosso) que se aplica à esfera de atuação do general português, uma possível arbitragem sobre o conflito. Deste modo, Sepé demonstra prudência aparentemente incompatível com sua impulsividade, e sobretudo com sua primitividade: 
“(..) e o vosso Mundo,

"Se nele um resto houver de humanidade,

"Julgará entre nós: se defendemos

“- Tu a injustiça, e nós o Deus e a Pátria” （II, 185-188)

Do confronto das falas dos três homens envolvidos na negociação fracassada sobressai a relativa neutralidade do poeta. Do ponto de vista estritamente lógico, as razões de cada um são tão aceitáveis quanto as dos outros, e, sobretudo, são sinceros todos eles. O poeta não lhes atribui perfídia nas negociações, que acontecem em clima de mútuo respeito, mesmo no caso do arrogante desafio de Sepé. A propósito, surpreende a refutação que Maria da Conceição Osório Dias Gonçalves pretende fazer da atribuição ao índios, por David Miller Driver, de "grandeza moral", com base no fato de que, "A par de índios como Cacambo ou Lindóia, aparece um Cepé cheio de ingratidão para com Andrade quanto este lhe entrega um arco e setas" (itálico nosso). ${ }^{35}$ A autora parece não ter compreendido o sentido afirmativo do gesto de Sepé, que recusa o presente que lhe dá o oponente não por ingratidão, mas em nome da liberdade irrestrita que advoga para si e para os seus e em nome da igualdade de condições que deve marcar as negociações diplomáticas com o invasor.

Devemos concluir que a idealização do índio existe, mas ela não se inclina apenas para a figuração singela do bom selvagem, ingênuo e natural, mas também para a sua elevação ao nível do homem branco, civilizado. Cacambo e Sepé discursam em pé de igualdade com o poderoso general português, e não apenas porque sejam favorecidos por circunstâncias eventuais: estão em seu habitat, move-os a emocionalidade da defesa da terra a qualquer preço; mas porque são dotados de qualidades de liderança complementares um em relação ao outro: a ponderação de Cacambo, a que não falta, porém, coragem, é correspondida pela impulsividade de Sepé, sem que este, por sua vez, seja desprovido de bom senso, como visto acima. Essa distribuição eqüitativa de virtudes entre os dois chefes guaranis serve ao engrandecimento da ação vitoriosa do herói do poema, fazendo dele o contendor capaz de tanto enfrentar armas - que os índios, aliás, não possuíam - quanto razões alheias.

Entretanto, de um modo geral, da perspectiva do poeta-narrador, a despeito de ter sua condição efetivamente elevada em relação às representações

35. GONÇALVES, 1961, p. 83. 
literárias anteriores a O Uraguai, o índio é ainda objeto de uma vontade superior, a dos padres jesuítas que, aproveitando-se de sua inocência, de sua condição de bom selvagem, o instigam contra o poder civil representado pelo general Gomes Freire de Andrade. Assim sendo, o serem inocentados da "perfídia" de livremente se oporem às determinações dos poderosos da Europa, pois são apenas instrumentos de que se valem os "bons padres", resulta na afirmação de sua recôndita inferioridade. Esses "bons padres" jesuítas são o alvo verdadeiro do discurso político do poeta-narrador, representam a reação obscurantista contra a racionalidade iluminista do Conde de Oeiras, futuro Marquês de Pombal. Os índios não são, no fundo, os verdadeiros culpados da afronta sofrida pelos reis de Espanha e de Portugal, de modo que o antagonista implícito do herói é a figura genérica do padre jesuíta, cuja Ordem era a responsável pela experiência das Colônias dos Sete Povos das Missões, e a quem o poeta, para caracterizá-la, reserva expressões alegóricas inteiramente negativas, tais como Ignorância, Inveja, Discórdia, Furor, Hipocrisia (Canto III, 274-276), e cuja obra junto aos índios é chamada de "infame República" (Canto V, 136).

Nesse embate entre os dois poderes, o da Companhia de Jesus, cujo braço armado seriam os índios inocentes, e o do general Gomes Freire de Andrade, representante dos governos de Portugal e de Espanha, o índio - "o rude Americano" - é duplamente derrotado: pelas armas, como de fato o foi no plano histórico, e pela prevalência da razão do colonizador, como pensa o poeta-narrador. O poeta, aliás, não se furta a mostrar o índio, no final do poema, inteiramente submisso, reconhecendo, na figura interposta do general vitorioso, o legítimo senhor de suas vidas:

Cai a infame República por terra.

Aos pés do General as toscas armas

Já tem deposto o rude Americano,

Que reconhece as ordens e se humilha,

E a imagem do seu rei prostrado adora;

(V, 136-139)

Entretanto, pelas circunstâncias já mencionadas, deve-se reiterar que acontece em O Uraguai uma indiscutivel elevação da figura do índio. As personagens do mundo indígena que vêm a primeiro plano são tratadas pelo poeta com respeito e mesmo simpatia. Além de Cacambo e Sepé, a "senhoril Lindóia", a fiel e destemida esposa de Cacambo, é-nos apresentada como tendo "costumes suavíssimos e honestos" (III, 157-158). Cabe-lhe, aliás, o privilégio funcional - 
importante, se levarmos em conta o propósito laudatório do poema-de, por artes da feiticeira Tanajura, ter a visão de Lisboa destruída pelo terremoto e sua reconstrução conduzida pelo Marquês de Pombal (III, 199-322). Por fim, a "Amável indiana" (IV, 210) merece do poeta a bela e antológica cena de sua morte: Lindóia, já viúva de Cacambo e "Cansada de viver" (IV, 150), ausentara-se da festa que o padre Balda promovia para celebrar seu casamento com o jovem Baldetta e "entrara no jardim triste e chorosa,/ Sem consentir que alguém a acompanhasse." (IV, 138-139). Ali se deixa picar por uma serpente e, morta, é encontrada pelo irmão, Caitutu. De Lindóia diz então o poeta:

Inda conserva o pálido semblante

Um não sei quê de magoado e triste,

Que os corações mais duros enternece.

Tanto era bela no seu rosto a morte! (IV, 194-197).

Mesmo as figuras de segundo plano recebem tratamento favorável, sobretudo no que diz respeito à bravura, comum a todos eles, com exceção apenas do indigitado Baldetta, que se cobre "de eterna infâmia" (II, 255) ao fugir do combate, assustado e ridículo. Considerando-se a insinuação de que Baldetta seja filho do padre Balda, mestiço, portanto, sua fraqueza não macula a integridade indígena, servindo antes como reforço ao empenho denegridor que o poeta desenvolve contra os jesuítas. Diz Basílio da Gama, numa das notas, que os jesuítas da América "não eram tão escrupulosos como afetavam ser os da Europa" e que era "bem fácil distinguir nas aldeias as índias que gozavam do favor dos padres." ${ }^{36}$ De Tatu-Guaçu, diz o poeta: é "o mais valente/ De quantos índios viu a nossa idade," (II, 270-271). Caitutu, "de régio sangue/ E de Lindóia irmão" (IV, 83-84), aparece à frente de um grupo de índios apresentados como "Não muito fortes", é verdade, mas "tão destros/ No exercício da frecha que arrebatam/ Ao verde papagaio o curvo bico,/ Voando pelo ar. (...)" (IV, 84-88). Caitutu era "altivo e forte/ Opunha o peito à fúria do inimigo/ E servia de muro à sua gente." (II, 306-309). Pindó, sucessor de Sepé no comando das forças indígenas, por sua vez, surge à frente dos tapes, "que se afrontam/ E que têm por injúria morrer velhos" (IV, 81-82). Até mesmo a "enrugada" Tanajura, a velha feiticeira responsável pela única manifestação do maravilhoso, de procedência

36. GAMA, 1972, p. 105. 
indígena, aliás, no poema - e, de passagem, deve ser ressaltado, em favor de Basílio da Gama, que o poeta não expressa qualquer reserva em relação a esse maravilhoso não-cristão, o que não deixa de ser um modo de valorizar o universo indígena -, pois cabe a ela, como já dito, assoprando as águas e proferindo "ímpias palavras", permitir a Lindóia a antevisão de Lisboa destruída pelo terremoto e reconstruída pelo marquês de Pombal, (III, 209-254), é retratada com palavras amistosas - era "prudente e experimentada" e tinha grande afeto por Lindóia, "a quem amava como filha" (III, 209).

A antropofagia, dos maiores estigmas na consideração do universo indígena americano, é mencionada apenas de passagem, e sem tintas de crueldade, antes, pelo contrário, em tom compreensivo. Na apresentação de Cobé, de quem nos é dito que é "disforme e feio", um dos poucos reparos assim negativos na descrição dos indígenas, o poeta diz que ele "Traz consigo os salvages da montanha,/ Que comem os seus mortos" (69-70, itálico nosso). Além da forma restritiva seus mortos, deixando claro que a antropofagia não se exercitava indiscriminadamente, comparece a ressalva atenuadora: fazem-no não por gula ou ferocidade, e sim por impulso amoroso, pois não

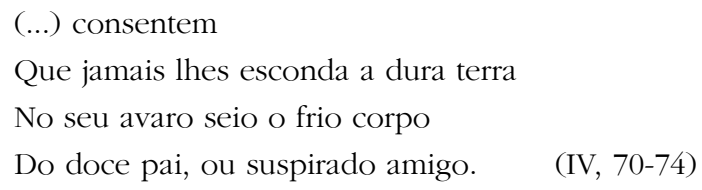

Contrariamente a isso, somente epítetos negativos são reservados aos jesuítas, sobretudo ao padre Balda, em quem se personifica a vilania da ordem religiosa, incitador da crueldade de queimar Tanajura (IV, 223-226), mesquinho e covarde, como o provam as palavras que profere na hora da fuga, ante a proximidade da chegada do herói vencedor: "Perca-se o mais, salvemos a cabeça." (IV, 241); e o ridículo irmão Patusca, "De pesada, enormíssima barriga" (IV, 115), flagrado pelo olhar implacável do poeta a fugir levando consigo os "paios saborosos e os vermelhos/ Presuntos europeus" (V, 121-122). A igreja edificada sob as ordens dos padres é descrita no final do poema como tão suntuosa ilustração das nefandas conquistas da Companhia que o poeta confessa a incapacidade de o verbo poético de tudo dar conta (V, 1-85): 
Em roda, os seus fortissimos guerreiros [de Andrade]

Admiram, espalhados, a grandeza

Do rico templo e os desmedidos arcos,

As bases das firmíssimas colunas

$\mathrm{E}$ os vultos animados, que respiram.

$\mathrm{Na}$ abóboda o artífice famoso

Pintara... mas que intento! as roucas vozes

Seguir não podem do pincel os rasgos

(IV, 276-283)

Pode-se dizer que O Uraguai prenuncia, sim, o indianismo romântico de Gonçalves Dias e José de Alencar, mesmo considerando-se a posição secundária do índio, de vez que o herói do poema é, sem sombra de dúvida, o general português Gomes Freire de Andrade. A altaneria dos índios românticos de Gonçalves Dias, sempre ciosos de seus emblemas de retidão moral, avessos ao convívio amistoso com o conquistador branco, cuja chegada o espectro que se mostra ao Piaga descreve como "desfile de horrores", no "Canto do Piaga":

Não sabeis o que o monstro procura?

Não sabeis a que vem, o que quer?

Vem matar vossos bravos guerreiros,

Vem roubar-vos a filha, a mulher!

Vem trazer-vos crueza, impiedade -

Dons cruéis do cruel Anhangá;

Vem quebrar-vos a maça valente,

Profanar Manitôs, Maracás.

Vem trazer-vos algemas pesadas,

Com que a tribo Tupi vai gemer;

Hão-de os velhos servirem de escravos

Mesmo o Piaga inda escravo há de ser $?^{37}$

já está muito bem anunciada em Sepé e Cacambo, sobretudo no primeiro, mais incisivo nos embates verbais com Gomes Freire de Andrade, embora caiba ao segundo a mais vigorosa imprecação contra a presença do homem branco na América:

37. DIAS, 1959, p. 108. 
"Gentes da Europa, nunca vos trouxera

"O mar e o vento a nós. Ah! não debalde/

"Estendeu entre nós a natureza/

"Todo esse plano espaço imenso de águas." ～(II, 171-174)

E o donaire de Lindóia, sua irrestrita fidelidade ao amado Cacambo, sua morte dolorosa e voluntária para não entregar-se ao odioso Baldeta, tudo na "Amável indiana" prenuncia Iracema.

Abstract: In O Uraguai by Basilio da Gama, the representation of the indian is divided enters the idealization that it intends to see in it the good savage and one another one, that raises it to the condition of illustrated opponent of the hero of the poem. The poem is not example of dither of the brasilidade, therefore the native element is defeated by the weapons and the reason of the europeans, but the positive attributes of the indian and the displacement of the negative condition of antagonist for the Jesuit priests allow to see it as anticipatory of the romantic indianism.

Key words: Brazilian literature; Neoclassical tradition; Epic poetry; Basílio da Gama.

\section{Referências Bibliográficas}

CANDIDO, Antonio. O disfarce épico de Basílio da Gama. In: Formação da literatura brasileira. (Momentos decisivos). $1^{\circ}$ Volume (1750-1836). 4. ed. São Paulo: Martins, s.d. p. $127-136$.

CANDIDO, Antonio. A dois séculos d" O Uraguai. In: Vários escritos. 2. ed. São Paulo: Duas Cidades, 1977. p. 161-185.

CASTELLO, José Aderaldo. Manifestações literárias da Era Colonial (1500-1808/1836). 3. ed. São Paulo: Cultrix, 1969.

CHAVES, Vânia Pinheiro. O despertar do gênio brasileiro: uma leitura de O Uraguai de José Basílio da Gama. Campinas: Editora da Unicamp, 2000.

DIAS, Gonçalves. O Canto do Piaga. Primeiros cantos. Poesias Americanas. In: Gonçalves Dias. Poesia completa e poesia escolhida. Rio de Janeiro: Nova Aguilar, 1959. p. 101-120.

DRIVER, David Miller. The Indian in brazilian literature. New York: Hispanic Institute in The United States, 1942.

GAMA, Basílio da. O Uraguai. Por Mário Camarinha da Silva. 2. ed. Rio de Janeiro: Agir, 1972 . 
Disponivel em: bttp://www.letras.ufmg.br/poslit

GOMES, Eugênio. A poesia de Basílio da Gama. In: Visões e revisões. Rio de Janeiro: Instituto Nacional do Livro-MEC, 1958. p. 38-45.

GONÇALVES, Maria da Conceição Osório Dias. O índio do Brasil na literatura portuguesa dos séculos XVI, XVII eXVIII. Coimbra: Faculdade de Letras da Universidade de Coimbra, 1961.

HOLLANDA, Sérgio Buarque de. A Arcádia heróica. In: Capítulos da literatura colonial. Org. Antonio Candido. São Paulo: Brasiliense, 1991. p. 116-174.

LUCAS, Fábio. Do mecenato à criação poética. Cult-Revista Brasileira de Literatura, São Paulo, n. 29, p. 10-13, dez. 1999.

PEIXOTO, Afrânio. Nota preliminar. In: GAMA, Basílio da. Uraguai. Rio de Janeiro: Academia Brasileira de Letras, 1941. p. vii-xxxvi.

PINHEIRO, Cônego Fernandes. Curso de literatura nacional. 3. ed. Rio de Janeiro: Cátedra; Brasília: Instituto Nacional do Livro-MEC, 1978.

ROMERO, Sílvio. História da literatura brasileira. Tomo Segundo. Formação e desenvolvimento autonômico da literatura nacional. 6. ed. Rio de Janeiro: José Olympio, 1960.

SILVA, Anazildo Vasconcelos da. Formação épica da literatura brasileira. Rio de Janeiro: Elo, 1987.

SILVA, Mário Camarinha da. Apresentação. In: GAMA, Basílio da. O Uraguai. 2. ed. Rio de Janeiro: Agir, 1972. p. 5-18.

TEIXEIRA, Ivan. Epopéia e modernidade em Basílio da Gama. In: Obras poéticas de Basílio da Gama. São Paulo: Editora da Universidade de São Paulo, 1996. p. 15-168.

TEIXEIRA, Ivan. O Uraguay como alegoria do mecenato pombalino. In: Mecenato pombalino e poesia nbeoclássica. São Paulo: Editora da Universidade de São Paulo, 1999. p. 467-536.

TEIXEIRA, Ivan. Resposta a Fábio Lucas. Cult - Revista Brasileira de Literatura, São Paulo, n. 29, p. 11, dez.1999.

VERÍSSIMO, José. Duas epopéias brasileiras. In: Estudos de literatura brasileira. 2. Série. Belo Horizonte: Itatiaia; São Paulo: EDUSP, 1977. p. 55-75. 